\title{
IMPORTANCE OF THE ORGANISATIONAL SUCCESS FACTORS ACCORDING TO THE ORGANISATIONAL CHARACTERISTICS
}

\author{
Olga Uhabakin ${ }^{1}$, Eneken Titov ${ }^{2}$ \\ Estonian Entrepreneurship University of Applied Sciences, Suur-Sõjamäe 10a, Tallinn, Estonia \\ E-mails: ' ${ }^{\prime}$ lga.uhabakin@eek.ee (corresponding author); ${ }^{2}$ eneken.titov@eek.ee
}

Received 01 April 2020; accepted 07 May 2020

\begin{abstract}
Every organization strives for success, but it is not easily definable or measurable. The success of the organization must be determined by using different factors, different approaches and methods. The aim of this article is to identify organizational success factors and its' relationship with organisational main characteristics (size, age, sector). Using an extensive literature review and experts' assessment (questionnaire), an universal list of success basic factors and characteristics - based factors was created. The originality of the research stands in following that the model takes into account also the "soft" success metrics - bridging the literature focused on the financial factors view and on human-centred factors view on success and this research opens several possibilities for further researches and practical implementations and implications.
\end{abstract}

Keywords: organizational success, organizational success model, success criteria, assessment model, success metrics.

JEL Classification: M10.

\section{Introduction}

For years, organisational success has been a source of great controversy not only in the economic environment, but also in the scientific world and among ordinary people. Why does efficiency of organisations operating under equal environmental conditions differ? What is the key factor that brings more success to some organisations compared with others in the long run? Despite the topicality of identifying and understanding the essence of the organisational success, there is no common and clear definition of organisational success today (Siimon, 2006; Likierman, 2006; Barhatov \& Pletnjev, 2014, 2015). As a rule, financial and top managers set the goal of the organisation as a success, but they have no idea how to identify success and measure it with the help of measuring instruments (Barhatov \& Pletnjev, 2014).

Success is a social phenomenon (Romanjuk, 2009), and its definition is subjective since the nature of organisational success depends on who performs the assessment of success (Milekhina \& Adova, 2014). The analysis of scientific literature shows that there are different approaches to opening the concept of organisational success. Consideration should be given to a certain number of different aspects (Maltz et al., 2003; Siimon, 2006), and it is critical to identify key factors for success (Siimon, 2006; Sulakshin, 2013).
Defining organisational success is a challenge because of the complexity of this concept. Frequently, when talking about success, one actually means efficiency, effectiveness, viability (Barhatov \& Pletnjev, 2014). Simpson et al. (2012) also point out the difficulty of differentiating between success and performance concepts as success can be partially assessed by performance indicators.

The authors of this article aim to develop the measurement model of the organizational success, in which components and other characteristics can be customized according to the specific activity of organization. This is a hands-on study based on an analysis of research and theoretical approaches to the concept and nature of organizational success and measurement problems, and a pilot study conducted among active organizations to evaluate the applicability of the factors of success of the previously selected authors according to the specifics of the organization. As a result, a novel approach to measuring the success of the organization will be completed.

In order to meet the objective of the authors of the article, the following research tasks have been set forth:

- assess and analyze the relevance and applicability of organizational descriptors;

- create a model for measuring organizational success. 


\section{Previous research}

For years, organizational success was mainly based on financial indicators - turnover, profit margin, cost efficiency, price of share, growth in sales, etc. (Kaplan \& Norton, 1992; Flamholtz \& Aksehirli, 2000; Hammer \& Karilaid, 2002; Maltz et al., 2003; Likierman, 2006; Pärl, 2006; Siimon, 2006; Saparnis et al., 2009; Artemenko \& Barõšnikova, 2011; Barhatov \& Pletnjev, 2014), though in recent years non-financial factors have increasingly been taken into the account. This is largely due to the need to be future-oriented as the long-term success and development of organisation become important (Flamholtz \& Aksehirli, 2000; Gorenak \& Košir, 2012; Barhatov \& Pletnjev, 2014). Financial indicators tend to measure the past and therefore it is not possible to create a balanced model of organisational success based on those factors only (Balabonienė \& Večerskienè, 2015). It is particularly difficult to be performed in a dynamically changing external environment (Bakovnik, 2002; Maltz et al., 2003).

Talking about organisational success, the focus is often shifted towards setting economic goals and achieving them (Likierman, 2006; Siimon, 2006; Simpson et al., 2012; Barhatov \& Pletnjev, 2014; Milekhina \& Adova, 2014, 2017; Slobodtšikova, 2015). By exploring goals in more detail, Ioniţă (2013) distinguishes between financial (e.g. turnover growth and number of employees) and non-financial (e.g. satisfaction and well-being) goals and consequently refers to financial and nonfinancial factors of success.

Identifying and using the right indicators of success will increase organisational competitiveness and advantage ( $\mathrm{Ng}$ et al., 2011), which is also a major factor for efficiency and effectiveness ( $\mathrm{Si}$ imon, 2006; Blinov \& Ugrjumova, 2013; Barhatov $\&$ Pletnjev, 2014). Critical factors for competitiveness are the ability to generate and implement organisational changes (Blinov \& Ugrjumova, 2013), the ability to think differently (Ng et al., 2011) and the ability to change (Siimon, 2006; Likierman, 2006; Saparnis et al., 2009; Bhalla et al., 2011; Blinov \& Ugrjumova, 2013), although the process of change is initially at odds with the aspirations to stability and the need to develop an organisation and human resources (Blinov \& Ugrjumova, 2013).

Changes that are constantly taking place in the external environment put organisation in a position to be as flexible as possible and to adapt quickly to all kinds of changes. Behind the succeeding this task is the perception of change and the initiation of preventive activities (Saparnis et al., 2009; Suhanov, 2018).

According to several studies, organisational success is directly related to organisational culture (Bhalla et al., 2011; Tshukudu, 2014; Suhanov, 2018), values (Romanjuk, 2009; Bhalla et al., 2011; Tshukudu, 2014; Titov \& Umarova, 2017; Preuss, 2018; Suhanov, 2018) and commitment of employees (Kaliannan \& Adjovu, 2015; Chamorro-Premuzic et al., 2018). It can be said that the most successful organisations are characterised by strong organisational culture (Bhalla et al., 2011; Tshukudu, 2014) and value-based management (Romanjuk, 2009), where shared organisational values are highlighted (Bhalla et al., 2011; Tshukudu, 2014) and employees are highly satisfied, motivated and committed to work (ChamorroPremuzic et al., 2018). The impact of organisational culture extends beyond the long-term success of organisation (Barrett, 2010), including organisational efficiency (Valentino \& Brunelle, 2004) and performance (Cameron \& Quinn, 2011).

In addition to the organisational success factors mentioned above, success is determined by the following factors: leadership (Madanchian et al., 2017), management style (Jermolina, 2013), agility (Holbeche, 2018), employees (Kaliannan \& Adjovu, 2015; Pletnjev \& Nikolajeva, 2016; Criveanu \& Cârstina, 2018), customer relationships (Pletnjev \& Nikolajeva, 2016), organisational learning (V. Saadat \& Z. Saadat, 2016), organisational sustainability (Blinov \& Ugrjumova, 2013; Lafontaine \& Shaw, 2014; Romanjuk, 2009), reputation (Romanjuk, 2009; Alfoqahaa, 2018; Maurya \& Agarwal, 2018) and many others.

When measuring organisational success, one should keep in mind that success is a temporary characteristic and may change at different stages of organisational development (Likierman, 2006; Siimon, 2006; Flamholtz, 2009; Artemenko \& Barõšnikova, 2011). According to a differentiated approach to the success factors presented by $\mathrm{Si}$ imon (2006), apart from the development stage of enterprise, the size of organisation must be taken into the account when determining the success rates, as the importance of factors may vary (Flamholtz, 2009). Other authors also consider it important to select and implement an operational strategy, the technologies deployed and the specificities of industry (Maltz et al., 2003; Artemenko \& Barõšnikova, 2011) as well as the competitive external environment (Artemenko \& Barõšnikova, 2011). In their study, Artemenko and Barõšnikova (2011) draw attention to the fact that indicators of different categories are suitable for measuring suc- 
cess, while several indicators are fundamental, i.e. basic indicators that are important for all organisations.

In terms of organisational success such factors as simplicity, dynamism, time flexibility, complexity, reliability and availability (Maltz et al., 2003; Likierman, 2006; J. N. Lapõgin \& D. J. Lapõgin, 2009; Milekhina \& Adova, 2014) are important, and, consequently, to the improvement manifested (Maltz et al., 2003). Organisational management should be involved in the selection of factors to measure, which in turn will ensure that the factors are relevant to the organisation's strategy, goals and objectives. At the same time, the management have information about the past, the present and the future (Maltz et al., 2003).

Taking the above into account, it can be stated that defining organisational success in a scientific environment is problematic and there is a range of different approaches. The common idea here is that today, in addition to financial indicators, there are important non-financial indicators that support a holistic view on organisational success.

\section{Methodology}

In accordance with the set objective and research tasks, the authors conducted an empirical pilot study within active organizations, which assessed the adaptability and applicability of the descriptors of the success of the selected organization according to the specifics of the organization. In order to avoid judging the organizations that participated in the pilot study and analyzing the results in a more general way, the data processing and interpreting the results were performed treating all respondents anonymously.

A pilot study was conducted in the spring of 2019 and the sampling consisted of operating organizations regardless of their background, field of activity or number of employees. For the sake of simplicity and convenience, the most accessible organizations were selected from the authors' circle. Since the convenience sampling is an unlikely sampling, the authors sent invitations to the owners and managers of organizations of different backgrounds (size, sector, industry, etc.) to represent the study. A total of 539 invitations were sent to the organisatsions with different type background to ensure the reliability of the results of the analysis.

A more detailed overview of the pilot study process is given in Figure 1.

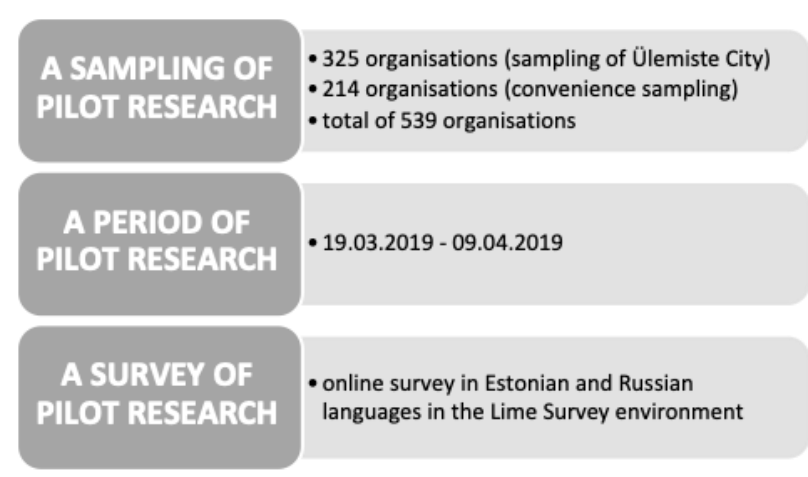

Figure 1. Pilot study process

The pilot study questionnaire conducted in the framework of this article is the result of a theoretical study and an analysis of peer review by previous authors. The short creaton process of the questionnaire is given in the Table 1 .

Table 1. The questionnaire creaton process

\begin{tabular}{|l|l|}
\hline \multicolumn{1}{|c|}{ Step/method } & \multicolumn{1}{c|}{ Result } \\
\hline $\begin{array}{l}\text { Mapping of organi- } \\
\text { zational success } \\
\text { factors (literature } \\
\text { review) }\end{array}$ & $\begin{array}{l}\text { 68 articles; } \\
430 \text { organizational success } \\
\text { factors/criteria. }\end{array}$ \\
\hline $\begin{array}{l}\text { Categorization of } \\
\text { organizational suc- } \\
\text { cess factors (expert } \\
\text { analysis) }\end{array}$ & $\begin{array}{l}\text { Organized and systematic list } \\
\text { of organization success factors } \\
189 \text { internal factors (9 catego- } \\
\text { ries); } \\
25 \text { external factors; } \\
17 \text { general characteristics. }\end{array}$ \\
\hline $\begin{array}{l}\text { Formation of the } \\
\text { subcategories } \\
\text { (questionnaire) }\end{array}$ & $\begin{array}{l}103 \text { factors describing the } \\
\text { organizational succes (8 cate- } \\
\text { gories). }\end{array}$ \\
\hline
\end{tabular}

The pilot study questionnaire consists of two parts. The first part of the questionnaire contains 7 questions to identify background information and to form a socio-demographic profile of respondents. The second part of the questionnaire consists of 103 organizational success factors divided into 8 blocks according to the following pre-formed categories: strategy, structure, processes, leadership style, values, personnel, skills and finance. The categories consist of two to twenty-four factors. Two estimates have been used for each factor. The first assessment concerns the respondent's assessment of the importance of an organizational success factor in the context of his or her own organization (scale 1), while the second assessment concerns the respondent' assessment of the same factor in his or her own organization (scale 2). A 
more detailed overview of the rating scales used in the survey is given in Table 2 .

Table 2. Assessment scales used for the pilot survey

\begin{tabular}{|l|l|c|}
\hline \multicolumn{1}{|c|}{ Scale 1 } & \multicolumn{1}{|c|}{ Scale 2 } & \multicolumn{1}{c|}{$\begin{array}{c}\text { Primary } \\
\text { coding }\end{array}$} \\
\hline Importance & $\begin{array}{l}\text { Measuring } \\
\text { feasibility }\end{array}$ & \\
\hline Very important & Very easy & 4 \\
\hline Important & Easy & 3 \\
\hline Less important & Complicated & 2 \\
\hline Unimportant & $\begin{array}{l}\text { Very } \\
\text { complicated }\end{array}$ & 1 \\
\hline Cannot answer & Cannot answer & 0 \\
\hline
\end{tabular}

Data processing and analysis is done using MS Excel spreadsheet software. The main statistical methods used for the analysis are the arithmetic average and standard deviation sample estimation. In addition, as a result of factor analysis and correlation analysis, the factors describing the success of the organization were categorized.

\section{Results and discussion}

The authors analyzed the evaluations of the organizations participating in the pilot study on the factors describing the success of the organization and their measurement, based on both the general assessment and the specificity of the organization. Besides, the analysis of the pilot study results includes comparisons with expert assessments (a theoretical study previously conducted by the authors).

\subsection{Profile of respondents to the pilot study}

To assess the applicability of the factors that characterize the success of an organization, a questionnaire was created in the LimeSurvey survey environment and sent to the sampling via email. By the end of the pilot study period, a total of 214 questionnaires had been received. 77 questionnaires were incomplete, and their answers were not used in the analysis. Thus, 137 questionnaires were taken for analysis. Regardless of the fact that the convenience sampling is an unlikely sampling, the authors estimate that the socio-demographic profile of the respondents is sufficiently representative.

The majority of the surveyees were managers or board members of organizations (59\%). The organizations, according to the respondent's own classification, represent all three sectors, but the highest share was in the private sector $(72 \%)$. The tertiary sector (86\%) became the largest area of activity among organizations.

\subsection{Overall results of the pilot study on the success factors of the organization}

In the pilot study, the respondents' estimates of the importance of organizational success factors, on a 4-point average, ranged from 1.97 to 3.83 , which is very similar to expert judgment. Most highly the respondents rated customer satisfaction $(\bar{x}=3.83$, expert rating $(\bar{x}=3.85))$ and product / service quality $(\bar{x}=3.66$, expert rating $(\bar{x}=3.85)$ ). According to data analysis, both experts and organizations are unanimous in their assessments, choosing the same factors as the most important factors that characterize the success of an organization.

Respondents in the survey also valued highly teamwork $(\bar{x}=3.61$, expert rating $(\bar{x}=3.38))$, customer relationships $(\bar{x}=3.61$, expert rating $(\bar{x}=$ 3.69)), and cooperation with clients $(\bar{x}=3.56$, expert judgment $(\bar{x}=3.54)$ ).

When evaluating factors that describe organizational success in the context of their organization, respondents did not share the same opinion in their assessments, and the range of standard deviations differed from those of experts (organizations $0.43-1.22$, experts $0.36-1.03$ ). The biggest standard deviations among the participants in the pilot study were in the category of "finance" when evaluating factors that describe an organizational success: earnings per share (EPS) $(\mathrm{SD}=1.22)$, stock price increases $(\mathrm{SD}=1.17)$, stock market value $(\mathrm{SD}=1.14)$, and economic value added $(\mathrm{EVA})$ $(\mathrm{SD}=1.14)$. The respondents shared a unanimous opinion only regarding the customer satisfaction factor $(\mathrm{SD}=0.43)$.

In addition to assessing the importance of the category factors that describe the organizational success, the participants assessed how easy/difficult it would be to measure the proposed factor in their organization. The easiest way is to measure the "processes" and "financial" factors, which include delivery times $(\bar{x}=3.00)$, occupational safety and health $(\bar{x}=2.98)$, sales growth $(\bar{x}=2.97)$, solvency $(\bar{x}=2.96)$, net profit margin $(\bar{x}=2.95)$, and employee education level $(\bar{x}=2.95)$.

\subsection{Overall results of the pilot study by catego- ry of factors that describe the organizational success}

Analyzing the results by category of factors describing organizational success, it may be noted as a positive example that no significant differences between the evaluations of the experts and the participants in the pilot study were mentioned. Some- 
what higher than the experts, the organizations rated the categories of factors that describe organizational success in terms of structure, staffing and staff skills. Lower than the peer review, ratings were found in the "processes", "management style" and "values" categories. The greatest difference in the indicators was observed when evaluating the factors of the "finance" category (a difference of +0.42 ). When interpreting these results, it should be considered that the difference in standard deviation for the "finance" category is also greater than the difference for the other categories $(+0.32)$, indicating that the participants in the pilot study have different opinions on the subject.

In order to test the relationship between the factors describing organizational success, the authors performed a factor analysis, grouping the factors into the so-called "hard" and "soft" factors according to the McKensey 7S model (McKinsey \& Company, 2008); the "finance" category was handled separately. The result of the factor analysis showed a strong correlation between the factors by category. In addition to factor analysis, the authors analyzed correlation coefficient values. Correlation analysis showed a strong correlation between factors across categories.

\subsection{Overall results of the pilot study by major factors describing organizational success}

The next step was to compare the rankings based on the evaluations of experts and organizations participating in the pilot study. Supported by the averages of respondents' ratings, the authors took the first 30 factors describing organizational success for analysis. As the factors ranked 30th and 31 st in the peer review ranked just as high, the rankings of the experts expanded to 31 factors.

Analysis of the evaluations of the experts and the organizations responding to the survey revealed that only 4 of the organizations describing organizational success are represented in all three scoreboards, which means that both the experts who gave the overall rating and respondents from organization, who assessed factors based on the specificity of their organizations, and, additionally, rated the ease/complexity of measuring the proposed factors internally within the organization, have identified these factors as important and noted that they are relatively easy to measure. These factors are customer satisfaction $\left(\mathrm{ET}^{1}(1), \mathrm{OT}^{2}(1), \mathrm{OM}^{3}\right.$ (12)), product/service quality (ET (2), OT (2), OM

\footnotetext{
${ }^{1}$ Experts' assessment to the importance of the factors.

${ }^{2}$ Top-managers' assessment to the importance of the factors.

3 Top-managers' assessment to the measuring possibility of the factors.
}

(18)), customer relationships (ET (7), OT (4), OM (31)) and skills development and qualification upgrading (ET (19), OT (12), OM (28)).

The 14 factors describing organizational success are important to both target groups, but they are not easy to measure for an organization. Analyzing the comparisons of the key factors of experts and organizations, it is obvious that the results presented show big discrepancies in practically every factor describing organizational success. The biggest gap was in the sequence of the teamwork factor. According to experts, teamwork is ranked 29th, hovewer, organizations have ranked it highly, placing it third. Apart from the teamwork factor, there were other notable cracks that ranged from 12 to 15 . Experts placed competitiveness (gap -13) and market response (gap -15) above organizations. According to experts, employees' trust in leaders (board of management) (difference +12 ) and the level of trust in the organization (difference +13 ) have gained a lower position than organizations.

For experts, a range of financial factors (ROE, stock market value, profit growth and net profit margin) is important for measuring the success of an organization, but the organizations themselves did not agree on the ratings. Thus, the "finance" category is not represented in the list of key factors. At the same time, it should be noted that, in experts' opinion, the measurement of important financial factors supported by the assessments given by organizations is not difficult. Separately, the rate of achievement of the goal, which is considered important by organizations and is not difficult to measure, was identified, though, according to experts, this factor was not very important in measuring organizational success.

\subsection{Results of the pilot study depending on the specifics of organization}

The authors analyzed the homogeneity of the assessments of the organizational success factors of the respondents in the pilot study across organizational characteristics such as size of organization, age of organization, legal form of organization and sector of activity. The rankings of the most important organizational success factors identified by the analysis, based on the specifics of the organization, include 12 organizational success factors, in order of importance, for each of the characteristics of the organization identified. The limited number of factors taken into consideration for analysis is justified by the fact that the multiplicity of factors in the model for measuring the success of a creative 
organization may complicate introducing the model in the organization.

The results of the ranking analysis show that, on average, compared to the list of main basic factors compiled using expert and organizational ratings, there are 7-9 overlapping factors that are considered important by the groups of organizations (top-managers). Depending on the specifics, most often the list of the basic factors describing organizational success coincide with general characteristics (list of the key factors) for respondents whose organizations operate in tertiary sector (10 factors are the same) and the least often in the primary and secondary sectors (6 factors are the same). In addition to organizations operating in the primary and secondary sectors, half of the key factors do not overlap for large organizations, i.e., organizations with more than 250 employees.

\subsection{Measuring key factors of organizational success in the pilot study}

Next, the organization' assessments of the importance of the organizational success factors and their measurement were compared. The result revealed that both the major single factors and the categories generally demonstrated large gaps in estimates (single factor range $0.22-1.05$; categorybased range $0.22-0.89$ ). There were no significant differences in the ratings of the "finance" and "structure" categories between the importance and measurement of the factors.

In other categories, there was a huge variance in importance and measurement ratings, which, on the one hand, indicates the importance of the factor in the context of organizational success and, on the other hand, implies that careful consideration should be given to the factor and the choice of appropriate instrument. Most of the assessments in the survey measured the need to act on the following factors: customer satisfaction (variance 0.94), competitiveness (variance 1.00), strategic management (variance 0.96), response to market needs (variance 1.00), employee motivation (variance 0.96), employee commitment (gap 0.98), and factors of trust (level of trust in organization - a gap of 1.05) and employee confidence in management -1.00 .

Furthermore, the authors analyzed the measurement ratings based on the specifics of the organization. For large organizations, it is easier to measure the high quality of production (variance 0.50) compared to medium-sized organizations. In small organizations, measuring organizational success is easier than in medium-sized organization in terms of employee engagement, encouragement to come up with ideas and proposals (gap 0.60), organizational synergy (gap 0.53) and trust factors (range from 0.51-0.65). The results illustrated that it is easier for private sector organizations to measure effective management decisions and the extent to which goals are achieved. Comparison of estimates from public and private sector organizations has proved that it is more difficult to measure cost efficiency, solvency and the retention rate of skilled workers in the public sector.

Authors of this article categorised and assembled the factors according to the results of the pilot study and compared the factors ocurancce with the previous studies (Table 3 ).

Table 3. Success factors of the pilot study compared to the previous studies

\begin{tabular}{|ll|l|}
\hline \multicolumn{2}{|c|}{ Factors describing organisational success } & \multicolumn{1}{c|}{ Previous studies } \\
\hline 1. & Customer satisfaction & $\begin{array}{l}\text { Maltz et al., 2003; Lönnqvist, 2004; Saparnis et al., 2009; Ng } \\
\text { et al., 2011; Titov \& Umarova, 2017; Pihel \& Paasma, 2017; } \\
\text { Alfoqahaa, 2018 }\end{array}$ \\
\hline 2. & Degree of achievement of goals & $\begin{array}{l}\text { Likierman, 2006; Siimon, 2006; Romanjuk, 2009; Simpson } \\
\text { et al., 2012; Barhatov \& Pletnjev, 2014; Milekhina \& Adova, } \\
\text { 2014, 2017; Slobodtšikova, 2015; Titov \& Umarova, 2017 }\end{array}$ \\
\hline 3. & Effective managerial decisions & Saparnis et al., 2009 \\
\hline 4. & Competitiveness & Saparnis et al., 2009; Barhatov, 2016 \\
\hline 5. & Partner satisfaction & Likierman, 2006 \\
\hline 6. & Efficiency of communication systems & Artemenko \& Barõšnikova, 2011 \\
\hline 7. & Strategic direction & Maltz et al., 2003 \\
\hline 8. & Clarity, transparency and simplicity of or- & Saparnis et al., 2009; Al-Mahrouq, 2010; Titov \& Umarova, \\
& ganizational structure & 2017 \\
\hline
\end{tabular}


End of Table 3

\begin{tabular}{|c|c|}
\hline Factors describing organisational success & Previous studies \\
\hline 9. Quality of product/service & $\begin{array}{l}\text { Maltz et al., 2003; Lönnqvist, 2004; Al-Mahrouq, 2010; } \\
\text { Naumova, 2017; Titov \& Umarova, } 2017\end{array}$ \\
\hline $\begin{array}{l}\text { 10. Development and improvement of prod- } \\
\text { ucts/services depending on needs }\end{array}$ & Al-Mahrouq, 2010 \\
\hline 11. Responding to market needs & $\begin{array}{l}\text { Maltz et al., 2003; Saparnis et al., 2009; Al-Mahrouq, 2010; } \\
\text { Artemenko \& Barõšnikova, } 2011\end{array}$ \\
\hline 12. Technological readiness & Al-Mahrouq, 2010; Naumova, 2017; Pihel \& Paasma, 2017 \\
\hline 13. High quality of production & Artemenko \& Barõšnikova, 2011 \\
\hline 14. Occupational health and safety of employees & Artemenko \& Barõšnikova, 2011 \\
\hline 15. Delivery time & Artemenko \& Barõšnikova, 2011 \\
\hline $\begin{array}{l}\text { 16. Involvement of employees, encouragment to } \\
\text { make proposals and suggest new ideas }\end{array}$ & Maltz et al., 2003; Kaliannan \& Adjovu, 2015 \\
\hline 17. Employee-driven management & Titov \& Umarova, 2017 \\
\hline 18. Teamwork & $\begin{array}{l}\text { Saparnis et al., 2009; Bhalla et al., 2011; Titov \& Umarova, } \\
2017\end{array}$ \\
\hline 19. Customer relationships & $\begin{array}{l}\text { Saparnis et al., 2009; Pletnjev \& Nikolajeva, 2016; Alfo- } \\
\text { qahaa, } 2018\end{array}$ \\
\hline 20. Collaboration with customer & Titov \& Umarova, 2017; Alfoqahaa, 2018 \\
\hline 21. Organizational synergy (cooperation) & Gabetž, 2015; \\
\hline 22. Relationships with partners & Pletnjev \& Nikolajeva, 2016 \\
\hline 23. Innovation & $\begin{array}{l}\text { Lönnqvist, 2004; Saparnis et al., 2009; Ng et al., 2011; Nau- } \\
\text { mova, } 2017\end{array}$ \\
\hline 24. Responsible and transparent organization & Naumova, 2017 \\
\hline 25. Level of competence of the staff & $\begin{array}{l}\text { Maltz et al., 2003; Lönnqvist, 2004; Saparnis et al., 2009; } \\
\text { Artemenko \& Barõšnikova, 2011; Pletnjev \& Nikolajeva, } \\
2016\end{array}$ \\
\hline 26. Rate of retention of key personnel & Maltz et al., 2003 \\
\hline 27. Number of skilled personnel & Al-Mahrouq, 2010; Naumova, 2017 \\
\hline 28. Rate of retention of qualified staff & Maltz et al., 2003; Al-Mahrouq, 2010 \\
\hline 29. Management trust in employees & Beheshtifar, 2013 \\
\hline 30. Employee motivation & Lönnqvist, 2004; Gabetž, 2015; \\
\hline 31. Level of trust in organization & Mctiernan, 2018 \\
\hline $\begin{array}{l}\text { 32. Development of skills and qualification of } \\
\text { employees }\end{array}$ & $\begin{array}{l}\text { Maltz et al., 2003; Saparnis et al., 2009; Al-Mahrouq, 2010; } \\
\text { Bhalla et al., 2011; Ng et al., 2011; Titov \& Umarova, } 2017\end{array}$ \\
\hline 33. Employee commitment & Kaliannan \& Adjovu, 2015; Chamorro-Premuzic et al., 2018 \\
\hline 34. Employee satisfaction & $\begin{array}{l}\text { Lönnqvist, 2004; Al-Mahrouq, 2010; Gabets, 2015; Titov \& } \\
\text { Umarova, 2017; Pihel \& Paasma, } 2017\end{array}$ \\
\hline 35. Employee trust in management & Osei \& Swing, 2018 \\
\hline 36. Cost-effectiveness & Gabets, 2015; Pihel \& Paasma, 2017 \\
\hline 37. Profit & $\begin{array}{l}\text { Maltz et al., 2003; Saparnis et al., 2009; Barhatov, 2016; Ti- } \\
\text { tov \& Umarova, 2017; Pihel \& Paasma, } 2017\end{array}$ \\
\hline 38. Solvency & Hammer \& Karilaid, 2002; Titov \& Umarova, 2017 \\
\hline
\end{tabular}

\section{Conclusions}

The prioritised factors are matched with the previous researches and every factor's effect on success is explained and proved.
As it was mentioned before, different authors have brought out factors which somehow affect organisational success. In this research the experts assessed the success factors and the most important 
ones were prioritised and were linked with the different organisational characteristics.

According to the characteristics of the organisation (size, age, sector etc) some of the factors are more or less important, but some success factors seems to be as important for every type of organisations (basic success factors), which in turn were divided into the five categories.

According to the size of an organisation, the large organisations (more than 250 employees) handled success differently and factors like strategic management, technological readiness and innovation are more important than in other size of organisation. At the same time small organisations preferred organisational synergy as success factor. For the middle size organisation the number of skilled employees seems to be essential.

The age of the organisation also adds some factors - young organisations (less than 5 years old) as small organisations value organisational synergy and innovation is important for all organisational despite of the age. The middle-aged organisations (5-10 years old) as middle-sized organisations value the number of qualified employees and organisations older than 10 years are used to assess success also through the implementation of objectives.

Division of organisation due to the sector (public, non-profit, primary, secondary and tertiary) affects the number of success factors the most. Not surprisingly the public sector values partner relations, organisational responsibility and transparency. Innovation and organisatsional synergy were not so expected from public sector, but confirm the popular opinion, that "soft" factors are more supported in public sector than "hard" ones. Only type of organisations which brought out employee satisfaction as an important success factor, was non-profit sector organisation. NGOs evaluate organisational success also through perfect leader's work referring to employees' opinion and responsible and transparent organization.

The analysis of the primary and secondary sector gave expected results - traditional organisational success factors were still prioritised and valued. As delivery time, employees' safety and high quality of products are all rooted in practices of this sector. The final model of the organisational success assessment model is given in the Appendix.

\section{Limitations}

Whether the orgainsational success is a wide term and may describe very different results of organisation, therefore, also the understanding of success factors can be really different. In this article, the authors didn't limit the organisational success with different models or schools, but the goal was to map the experts and practitionnaires understandings of success and its' factors in general. Further researces should pay more attention to the definition of the organisational success and its' relationship with the different factors. Also, business field may impact the imoportance of the success factors.

\section{References}

Alfoqahaa, S. (2018). Critical success factors of small and medium-sized enterprises in Palestine. Journal of Research in Marketing and Entrepreneurship, 20(2), 170-188.

https://doi.org/10.1108/JRME-05-2016-0014

Al-Mahrouq, M. (2010). Success factors of Small and Medium-Sized Enterprises (SMEs): The case of Jordan. Anadolu University Journal of Social Sciences, 10(1), 1-16.

Artemenko, V. G., \& Barõšnikova, N. C. (2011). Ocenka faktorov uspeha organizacii real'nogo sektora jekonomiki. Sibirskaja finansovaja shkola, 1(84), 99-105.

Bakovnik, R. (2002). Nova merila poslovne uspešnosti kot podlaga za učinkovito opravljanje nadzorne funkcije. Industrijska demokracija, 12.

Balabonienè, I., \& Večerskienè, G. (2015). The aspects of performance measurement in public sector organization. Procedia - Social and Behavioral Sciences, 213, 314-320. https://doi.org/10.1016/j.sbspro.2015.11.544

Barhatov, V. I., \& Pletnjev, D. A. (2014). Comparative analysis of the definition of „Business success“ in modern science. Bulletin of Chelyabinsk State University. Economic Sciences, 18(347), 8-18.

Barhatov, V. I., \& Pletnjev, D. A. (2015). Priroda, faktory i izmerenie uspeshnosti predprijatij malogo $i$ srednego biznesa $v$ Rossii. Monografija. Izdatel'stvo "Pero".

Barhatov, V. I. (2016). Evaluation criteria changes of small and meedium Business success in the evolution of the russian economy. Bulletin of Chelyabinsk State University. Economic Sciences, 6(388), 114-121.

Barrett, R. (2010). The importance of values in building a high performance culture. Barrett Values Centre. https://www.valuescentre.com/sites/default/files/upl oads/2010-07-06/The\%20Importance $\% 20$ of\% 20Values.pdf

Bhalla, V., Caye, J.-M., Dyer, A., Dymond, L., Morieux, Y., \& Orlander, P. (2011). Highperformance organisations. The secrets of they success. The Boston Consulting Group. https://www.bcg.com/publications/2011/highperformance-organizations-secrets-of-success.aspx 
Blinov, A. O., \& Ugrjumova, N. V. (2013). Modern methods of resistance human resources.. Vestnik UGUES. Nauka. Obrazovanie. Ekonomika, 4(6), 76-80.

Cameron, K. S., \& Quinn, R. E. (2011). Diagnosing and changing organizational culture: Based on the competing values framework (3rd ed.). JosseyBass.

Chamorro-Premuzic, T., Garrad, L., \& Elzinga, D. (2018, December 21). Pochemu vam nuzhny ne tol'ko vovlechenonnye, no i nedovol'nye sotrudniki. Harvard Business Review: Menedzhment / upravlenie personalom.

https://hbr-russia.ru/management/upravleniepersonalom/789994

Criveanu, M. M., \& Cârstina, S. (2018). The importance of human resources within the strategic direction and organizational success. Proceedings of the International Conference on Business Excellence, 12(1), 229-240. https://doi.org/10.2478/picbe-2018-0021

Flamholtz, E. (2009). Towards using organizational measurements to assess corporate performance. Journal of Human Resource Costing \& Accounting, 13(2), 105-117. https://doi.org/10.1108/14013380910968629

Flamholtz, E. G., \& Aksehirli, Z. (2000). Organizational success and failure: An empirical test of a holistic model. European Management Journal, 18(5), 488-498. https://doi.org/10.1016/S0263-2373(00)00038-4

Gabets, O. (2015). Organizational efficiency. Ekonomika I menedzment innovatcionnyh tehnologi. http://ekonomika.snauka.ru/2015/09/9690

Gorenak, M., \& Košir, S. (2012). The Importance of organizational welfare to business success: Higher performance in healthy organizational environments. In Management, Knowledge and Learning International Conference (pp. 563-569). http://issbs.si/press/ISBN/978-961-6813-105/papers/ML12_117.pdf

Hammer, H., \& Karilaid, I. (2002). Investment evaluation and performance measurement: Survey of Estonian companies. In $X$ Tallinn Conference on the Management of Business Organizations (pp. 38-44).

Holbeche, L. S. (2018). Organisational effectiveness and agility. Journal of Organizational Effectiveness: People and Performance, 5(4), 302-313. https://doi.org/10.1108/JOEPP-07-2018-0044

Ioniţă, D. (2013). Success and goals: An exploratory research in small enterprises. Procedia Economics and Finance, 6(2013), 503-511. https://doi.org/10.1016/S2212-5671(13)00168-8

Jermolina, L. V. (2013). Economic maintenance of the category of "effectiveness". The concept of strategic effectiveness. Osnovy ekonomiki, upravlenija i prava, 2(8), 98-102.
Kaliannan, M., \& Adjovu, S. N. (2015). Effective employee engagement and organizational success: a case study. Procedia - Social and Behavioral Sciences, 172, 161-168. https://doi.org/10.1016/j.sbspro.2015.01.350

Kaplan, R. S., \& Norton, D. P. (1992). The balanced scorecard - measures that drive performance. Harvard Business Review, (January-February), 70-79.

Lafontaine, F., \& Shaw, K. (2014). Serial entrepreneurship: Learning by doing? (NBER Working Paper No. 20312). National Bureau of Economic Research. https://doi.org/10.3386/w20312

Lapõgin, J. N., \& Lapõgin, D. J. (2009). Biznes-plan: strategija $i$ taktika razvitija kompanii. Prakticheskoe izdanie. Moskva.

Likierman, J. A. (2006). Measuring company success. In A. Neely, M. Kennerley, \& A. Walters (Eds.), Performance measurement and management: public and private. (pp. 1027-1030). Performance Management Association, London.

Lönnqvist, A. (2004). Measurement of intangible success factors: Case studies on the design, implementation and use of measures. Department of Industrial Engineering and Management, Tampere University of Tehnology, Tampere, Finland.

Madanchian, M., Hussein, N., Noordin, F., \& Taherdoost, H. (2017). Leadership effectiveness measurement and its effect on organization outcomes. Procedia Engineering, 181, 1043-1048. https://doi.org/10.1016/j.proeng.2017.02.505

Maltz, A. C., Shenhar, A. J., \& Reilly, R. R. (2003). Beyond the balanced scorecard: Refining the search for organizational success measures. Long Range Planning, 36(2), 187-204. https://doi.org/10.1016/S0024-6301(02)00165-6

Maurya, K. K., \& Agarwal, M. (2018). Organisational talent management and perceived employer branding. International Journal of Organizational Analysis, 26(2), 312-330. https://doi.org/10.1108/IJOA-04-2017-1147

McKinsey \& Company. (2008). Enduring ideas: The 7-S Framework. https://www.mckinsey.com/business-functions/strategy-and-corporate-finance/ourinsights/enduring-ideas-the-7-s-framework

Milekhina, O. V., \& Adova, I. B. (2014). Metodicheskie podhody $\mathrm{k}$ issledovaniju fenomena uspeshnosti Rossijskih organizacij. Ekonomicheskij analiz: teorija i praktika, 47(398), 23-33.

Milekhina, O. V., \& Adova, I. B. (2017). Drajvery uspeha v biznese. Rossijskoe predprinimatel'stvo, 18(11), 1659-1670. https://doi.org/10.18334/rp.18.11.37848

Naumova, K. A. (2017). Analysis of the success factors of fast-growing companies of medium-sized business in russia. Bulletin of Chelyabinsk State University. Economic Sciences, 5(401), 139-148.

Ng, H. S., Kee, D. M. H., \& Brannan, M. (2011, October 27-28). The role of key intangible performance 
indicators for organisational success. In 8th International Conference on Intellectual Capital, Knowledge Management and Organisational Learning (pp. 779-787).

Osei, E. T., \& Swing, V. K. (2018). The relationship between leadership ethics and organizational success: ethics and organizational success. In F. S. Topor (Ed.), Advances in business strategy and competitive advantage (ABSCA) book series. Ethical standards and practice in international relations (pp. 22-48). IGI Global.

https://doi.org/10.4018/978-1-5225-2650-6.ch002

Pihel, L., \& Paasma, B. (2017). Mapping of appropriate measurement for evaluating an organisations' success. In EUAS Conference. Conference Proceedings no 5. Innovation and Entrepreneurship: Organizational and Social Capital as a Key for Future Success. Estonian Entrepreneurship University of Applied Sciences.

Pärl, Ü. (2006). Choice of measures for performance measurement models on the example of successful Estonian companies. Entrepreneurship in Estonia: Policies, Practices, Education and Research, 28, 228-247.

Pletnjev, D. A., \& Nikolajeva, E.V. (2016). Success of small and meedium Business in russia and the social responsibility of its leaders. Bulletin of Chelyabinsk State University. Economic Sciences, 6(388), 128-138.

Preuss, B. (2018). Organizational values and firm profitability: A financial and cultural perspective on Europe.

Romanjuk, D. M. (2009). Akmeologicheskie faktory uspeshnosti razvitija organizacii. Nauchnyj potencial: raboty molodyh uchenyh, 1, 247-250.

Saadat, V., \& Saadat, Z. (2016). Organizational learning as a key role of organizational success. ProcediaSocial and Behavioral Sciences, 230, 219-225. https://doi.org/10.1016/j.sbspro.2016.09.028
Saparnis, G., Bersenaite, J., \& Saparniene, D. (2009). Psychosemantics of employees' images when identifying the dimensions of changes and successful organisation. Inzinerine Ekonomika - Engineering Economics, 5, 67-77.

Siimon, A. (2006, jaanuar 20-21). Ettevõtte edutegurid. Pärnu IV ettevõttemajanduse konverentsi ettekanded - artiklid (pp. 180-189). Tallinn. Mattimar OÜ, Pärnu (in Estonian).

Simpson, M., Padmore, J., \& Newman, N. (2012). Towards a new model of success and performance in SMEs. International Journal of Entrepreneurial Behaviour \& Research, 18(3), 264-285. https://doi.org/10.1108/13552551211227675

Slobodtšikova, A. A. (2015). Podhody k opredeleniju ponjatija uspeshnost' predprijatija i izmereniju uspeshnosti malogo biznesa na primere Cheljabinskoj oblasti. Nauka HHI veka: problemy, poiski, reshenija (pp. 181-186). Izdatel'stvo “Geotur".

Suhanov, A. (2018, August 24). Sreda uspeha: kak sozdat' jeffektivnuju kul'turu v organizacii. Harvard Business Review Rossija. Menedzhment / korporativnyj opyt.

Titov, E., \& Umarova, L. (2017). Impact of real and propagated values on organisational success. IntechOpen. https://doi.org/10.5772/intechopen.69460

Tshukudu, T. T. (2014). Critical organisational success factors used in the evaluation of training \& development. Journal of Public Administration and Governance, 4(3), 2161-7104. https://doi.org/10.5296/jpag.v4i3.6502

Valentino, C. L., \& Brunelle, F. W. H. (2004). The role of middle managers in the transmission and integration of organizational culture. Journal of Healthcare Management, 49(6), 393-404.

APPENDIX

The organisational success assessment model

Factors concerning Strategy and Processes

\begin{tabular}{|l|l|l|}
\hline \multirow{2}{*}{ BASE FACTOR } & \multicolumn{1}{|c|}{ STRATEGY STUCTURE } & \multicolumn{1}{|c|}{ PROCESSES } \\
\cline { 2 - 3 } & Customer satifaction & Product/service quality \\
\cline { 2 - 3 } & Competitiveness & Respond to market needs \\
\cline { 2 - 3 } & Partner satisfaction & $\begin{array}{l}\text { Development and adjustment of the } \\
\text { products upon the needs }\end{array}$ \\
\cline { 2 - 3 } & $\begin{array}{l}\text { Clarity, transparency and simplicity of } \\
\text { organizatsion structure* }\end{array}$ & \\
\hline SMALL ORG-N Les than 49 emploees & & \\
\hline $\begin{array}{l}\text { MEDIUM ORG-N } \\
\text { 50 till 249 employees }\end{array}$ & & \\
\hline $\begin{array}{l}\text { LARGE ORG-N 250 employees and } \\
\text { more }\end{array}$ & $\begin{array}{l}\text { + The implementation of the objectives } \\
+ \text { strategic management }\end{array}$ & + Technological readiness \\
\hline THE AGE OF ORG-N Less than 5 years & & \\
\hline THE AGE OF OR-N 5 till 10 years & + effectiveness of communication sys- & \\
\hline
\end{tabular}




\begin{tabular}{|l|l|l|}
\hline & \multicolumn{1}{|c|}{ STRATEGY STUCTURE } & \multicolumn{1}{c|}{ PROCESSES } \\
\hline THE AGE OF ORG-N over 10 years & tems & + The implementation of the objectives \\
\hline PRIVATE SECTOR & & \\
\hline PUBLIC SECTOR & & \\
\hline NON-PROFIT SECTOR & & \\
\hline TERTIARY SECTOR & & $\begin{array}{l}\text { + delivery time } \\
+ \text { employees safety and healh-care } \\
\text { + high quality of products }\end{array}$ \\
\hline $\begin{array}{l}\text { PRIMARY AND SECONDARY } \\
\text { SECTOR }\end{array}$ & & \\
\hline
\end{tabular}

Factors concerning Management Style, Staff Capabilities and Finances

\begin{tabular}{|c|c|c|c|}
\hline & $\begin{array}{l}\text { MANAGEMENT STYLE } \\
\text { VALUES }\end{array}$ & $\begin{array}{c}\text { STAFF } \\
\text { CAPABILITIES }\end{array}$ & FINANCE \\
\hline \multirow[t]{7}{*}{ BASE FACTOR } & Client relationships & $\begin{array}{l}\text { Employee skills development and } \\
\text { capacity buiding for the employees }\end{array}$ & $\begin{array}{l}\text { Cost- } \\
\text { effective- } \\
\text { ness* }\end{array}$ \\
\hline & Cooperation with customers & Level of employees' competence & Profit* \\
\hline & $\begin{array}{l}\text { Emploee involving and encour- } \\
\text { agement to make suggestions and } \\
\text { test new ideas }\end{array}$ & Leaderships confidence to employees & Solvency* \\
\hline & Teamwork & Staff motivation & \\
\hline & & Degree of confidence in organization & \\
\hline & & Staff commitment & \\
\hline & & Management credibility & \\
\hline $\begin{array}{l}\text { SMALL ORG-N } \\
\text { Les than } 49 \text { emploees } \\
\end{array}$ & $\begin{array}{l}\text { + innovatsion } \\
+ \text { organization synergy }\end{array}$ & + retention rate of top employees & \\
\hline $\begin{array}{l}\text { MEDIUM ORG-N } \\
50 \text { till } 249 \text { employees } \\
\end{array}$ & + innovatsion & $\begin{array}{l}+ \text { Skilled workers at the organizatsion } \\
+ \text { retention rate of qualified staff } t\end{array}$ & \\
\hline $\begin{array}{l}\text { LARGE ORG-N } \\
250 \text { employees and more }\end{array}$ & + innovatsion & & \\
\hline $\begin{array}{l}\text { THE AGE OF ORG-N } \\
\text { Less than } 5 \text { years }\end{array}$ & $\begin{array}{l}\text { + innovatsion } \\
\text { + organization synergy } \\
\text { + Partner relations }\end{array}$ & & \\
\hline $\begin{array}{l}\text { THE AGE OF OR-N } \\
5 \text { till } 10 \text { years }\end{array}$ & + innovatsion & + number of qualified employee & \\
\hline $\begin{array}{l}\text { THE AGE OF ORG-N } \\
\text { over } 10 \text { years }\end{array}$ & + innovatsion & + retention rate of top employees & \\
\hline PRIVATE SECTOR & + innovatsion & + retention rate of top employees & \\
\hline PUBLIC SECTOR & $\begin{array}{l}\text { + innovatsion } \\
+ \text { partner relations } \\
+ \text { Responsible and transparent } \\
\text { organisation } \\
+ \text { organization synergy }\end{array}$ & & \\
\hline NON-PROFIT SECTOR & $\begin{array}{l}\text { + innovatsion } \\
\text { + organization synergy } \\
+ \text { Perfect leader's work referring } \\
\text { to employees' opinion } \\
+ \text { Responsible and transparent } \\
\text { organisation }\end{array}$ & + Employees satisfaction & \\
\hline TERTIARY SECTOR & + innovatsion & + retention rate of top employees & \\
\hline $\begin{array}{l}\text { PRIMARY AND } \\
\text { SECONDARY SECTOR }\end{array}$ & + organization synergy & & \\
\hline
\end{tabular}

\footnotetext{
4 *Additional factors based on the top-managers opinions.
} 